\title{
Erratum to: Fifty years of TCA
}

\author{
Christopher J. Cramer
}

Published online: 24 May 2012

(C) Springer-Verlag 2012

\section{Erratum to: Theor Chem Acc (2012) 131:1074 \\ DOI 10.1007/s00214-011-1074-x}

In the editorial celebrating fifty years of $T C A$, the editor inadvertently failed to include the names of five individuals in the list of past and current editorial board members. The list should have included

Batista, Victor

Head-Gordon, Teresa

Heilbronner, Edgar

Norrby, Per-Ola

Voth, Greg

The editor sincerely regrets the oversight and would like to thank all members of the TCA editorial board, past and present, for their many years of generous service.

The online version of the original article can be found under doi:10.1007/s00214-011-1074-x.

C. J. Cramer $(\square)$

Department of Chemistry, University of Minnesota,

207 Pleasant Street SE, Minneapolis,

MN 55455-0431, USA

e-mail: cramer@umn.edu 